\title{
Overestimation in the Growth Rates of National Income in Recent Years? - An Analyses Based on Extending GDP04-05 through Other Indicators of Output
}

\author{
Sebastian Morris \\ Tejshwi Kumari
}

W. P. No. 2019-01-01

January, 2019

The main objective of the working paper series of the IIMA is to help faculty members, research staff and doctoral students to speedily share their research findings with professional colleagues and test their research findings at the pre-publication stage. IIMA is committed to maintain academic freedom. The opinion(s), view(s) and conclusion(s) expressed in the working paper are those of the authors and not that of IIMA.

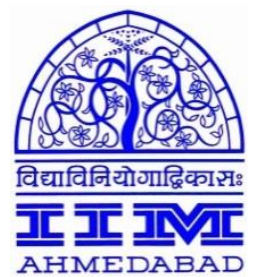

INDIAN INSTITUTE OF MANAGEMENT

AHMEDABAD-380 015

INDIA 


\title{
Overestimation in the Growth Rates of National Income in Recent Years? - An Analyses Based on Extending GDP04-05 through Other Indicators of Output
}

\author{
Sebastian Morris and Tejshwi Kumari ${ }^{1}$
}

\begin{abstract}
$\underline{\text { Abstract }}$
Quarterly indices of output like those of Industrial Production, other measures of production like net sales, exports, of companies for which data is available, besides proxies like credit to the sector, and indices of price levels have been used to forward project the growth rates of GDP04-05, for the principal sectors of the National Income Accounts (NAS). These were then compared with the growth rates given by the new Gross Value Added (GVA11-12) at constant price measure. It is very highly probable that some sectors of the National Accounts Statistics (NAS) notably Manufacturing, and Trade, Transport, Storage, Hotels and Communication Sectors were overestimated, especially in periods when the output (economic activity) was slowing down. This questions the use of the new GVA series for macroeconomic (policy) actions, wherein more than extensiveness of coverage, the movements over time of the measure have to be reliable and accurate. This is especially so because manufacturing and its related sector - trade etc., are the core sectors which are responsive to changes in policy and to shocks (that could be countered), wherein there is deep overestimation. Some evening out of the overestimation is noticed over the upswing in the business cycle since 2017:2. However the demonetization which rudely reduced demand did not allow the "phase shifting" and "flattening" aspects, which the new GVA series possibly imposes to be examined in detail, although the same is suggested.
\end{abstract}

Key words: India, Growth, National Income, New Series, Overestimation

${ }^{1}$ Prof. Sebastian Morris, Indian Institute of Management, Ahmedabad. Email: morris@iima.ac.in ; Ms. Tejshwi Kumari, Indian Institute of Technology, Kharagpur. Email: tejshwihappy@gmail.com; assisted with the computations. The views herein are the first author's alone. 


\section{INRODUCTION}

Ever since the Central Statistical Organisation (CSO) changed the method of computation of national output (income), from what was centered around final goods (GDP04-05) to a dominance of the use of estimates of value added across productive entities (GVA 2011-12 series), the growth rates from the latter series did not seem to reflect the reality.

Thus, (initially) the RBI in the April 2015 Monetary Policy Report stated "Consequent upon these changes, nominal levels of GDP on the new base are lower relative to the old base. Growth rates of both nominal and real GDP on the new base are higher for each year. In terms of commonly used indicators of productivity - the incremental capital output ratio (ICOR) - the new series reveals a significant improvement, but this is not corroborated by the behaviour of other indicators, especially in an environment characterized by declining national savings, investment and general concerns about stalled projects..." and further "In the manufacturing sector, GVA growth is much higher in the new series than in the earlier series. The growth of this sector appears to have been driven by the unorganised sector, which grew by 23.3 per cent in 2012-13". (RBI, 2015) The latter possibility was doubted by the RBI.

The RBI also added that "It is expected that the revised estimates for 2014-15 to be released by end-May 2015 will incorporate better information covering the second half of the year and provide greater clarity on the state of economic activity at the aggregate level." (RBI, 2015). However, there was no attempt to stay focused on the issue of the possible problems with the CSO's new measure in the many subsequent reviews of Monetary Policy. In the April 2017 Monetary Policy Review, without any comment the RBI merely mentioned that there was a great wedge between the growth in various quarters from the second quarter of 2014-15 to the third quarter of 2015-16 as measured by GVA at 11-12 constant prices and the IIP. Indeed, the difference was there in every quarter, with the difference in the last quarter being almost $10 \%$.

These estimates did not gel with factors that are well known to influence the short period growth -like credit expansion, exports, exports of services, all of which had slowed down from 2011-12. Also since then monetary policy was conservative, and the fiscal policy even after the withdrawn of the fiscal stimulus had turned conservative till almost 2015-16.

Similarly, the Economic Survey of 2014-15 cautioned the reader to the use of the new series in computing growth rates and hoped that with some years the issues would be ironed out. It noted that: "The upward revision in manufacturing growth in the new series also owes to inclusion of trade carried out by manufacturing companies in the manufacturing sector itself, which was earlier part of the services sector". (p. 5. Economic Survey 2014-15"). Since there has been not much official comment on the issue, and as the overlap period has gone past, the new series' estimates have been "accepted" by official authorities. Nevertheless, the fact that there could be such large differences is interesting until the same is resolved by statisticians with a deeper understanding of the processes and especially of the extrapolations that have been important in both the old and the new series. The matter continues to be important since the high growth rate of income as exhibited by the new series puts India in an exceptional position with growth above $7 \%$, at a time when much of the developing world following Chinese slow down grows very slowly ${ }^{2}$. Only the US has grown rapidly over the last several years, and that to have affected India positively should have acted through remittances, exports, and exports of services all of which have been subdued. Also it would make Indian ICORs one of the lowest among the Asian countries, which while not impossible would be very improbable with investments in India even when made by the private sector still suffer from delays and cost overruns, while the demand remains weak.

Modern empirically valid macroeconomics, whatever are the controversies, understands that in the short run it is demand that almost entirely determines the growth, even if demand itself could be influenced by uncertainity, animal spirits, internal shocks, external shocks including technology shocks. Even supply shocks (technology,

\footnotetext{
2 The marginal decline in growth rates by about a percent or so over the period after the global financial crisis (till 2011 12 in India, and till 2014-15 in China), in comparison to the six years before, can be attributed to the pursuit of massive fiscal counteraction in both India and China (of roughly US\$52b and 540b respectively), and not to any "special feature" of these economies, as claimed by many international observors.
} 
terms of trade) act by lowering the supply price of goods through falling inflation, but would involve movement along the aggregate demand curve, and hence would be reflected in the accounting sources of demand such as consumption, investment, government expenditure and exports, which as mentioned have not been exuberant.

Over the period where the two series overlap (2011:2 to 2014:3) the growth rate of GDP04-05 has been 5.4\% (average) is lower than that for the new series GVA11-12 at 6.7\%. The difference of $1.3 \%$ is disturbing since many quarters are involved and any initialising problem due to the change in the base year should have been reduced over these 14 quarters. Hence the difference is of serious concern. See Table 1 and Fig.1. The plots of growth rates of nominal GDP04-05 and GVA11-12 -Figs. 2 and 3 - would indicate that the divergence is due less to the deflators that have been used and more to the way the nominal GVA is arrived at. Considering only the overlap period, the implicit deflators differ by only $-0.1 \%$ (6.4 -6.5); while the nominal values differed in growth rates by $1.4 \%$, for the constant price values growing with a difference of $1.3 \%$. It is important to mention that we can add growth rates across time and across variables that multiply because we have use only the symmetric measure of growth rates, i.e., the exponential measures measure $-\ln (V(t) / V(t-1))$ and $\ln (V(t) / V(t-4))$ for annual and quarterly series respectively. See Table 1.

There has been much discussion on the need to be comprehensive in coverage for national income estimation. The large informal sector, and the believed to be large "black economy" according to many scholars demand a measure that is more comprehensive in coverage ${ }^{3}$. However, comprehensiveness cannot come at the cost of incorporating arbitrariness to the growth measure. This would be the case if too many imputations and/or extrapolations are made in enhancing the coverage. Social policy perhaps requires more comprehensive coverage, but then it does not require the fine discrimination across time that macroeconomic management would require. And hence a periodic quarterly measure that is blunted by the need for comprehensive coverage would be most useless to macroeconomists, government, and central bankers, who need the measure over quarters if not months, and that too with little delay ${ }^{4}$ to be able to effectively practice the art of macroeconomic management.

Nagaraj, R. (2015) notes in the context of the new series where the base as changed, the methodology, and the database (going from an ASI -Annual Survey of Industries - plant oriented estimation, to a MCA- Ministry of Corporate Affairs accounting data for productive enterprises) too have changed that: "Seldom, however is the case where the growth rates (in current and constant prices) vary with the base year revision, causing serious apprehension among data users" (p.15). Similarly, Dholakia, Nagaraj and Pandya (2018) disputed the claim that the older NAS oriented estimation systematically omitted the non-plant activities in manufacturing since as a norm these were allocated

\footnotetext{
${ }^{3}$ The idea that black incomes are not captured may only be partly true, since with the use of many methods including the final goods approach, it is possible to count the output of the activities from such economic activities where taxes have not been paid - consultants, traders, agriculturists, doctors etc. However, the larger part of the black "income" generation is in the form of rents, earnings from crime, and avoidance of taxes unrelated to income generation kickbacks, avoidance of transaction taxes on asset (land) sales, criminals' activities, diversion of state subsidies and transfers, etc., and which can hardly be considered as income generation. However, these would affect the disposable incomes across various groups, government revenues, as also the savings rates out of disposable incomes across various groups. Indeed, the demonetization which was predicated on the belief that the former aspect was the more significant one, and also on the assumption that cash was the main mode of holding on to the savings out of black income, both of which were false, was therefore bound to fail on the objective of curbing the black economy. However, the GST which brings higher recording probability from at least one end of trade transactions has a better chance of overcoming the generation of black income from economic activities, if the smaller producers and traders are also brought into the network.

${ }^{4}$ Moreover if the true output is $Y$ and the measured value is $X$, while $X=\beta Y$; as long as the degree of coverage $\beta$ does not change, then growth rate as estimated by $X$ is a good reflection of growth in $Y$. It is only when there are sudden changes that there is a problem. Slow changes in $\beta$ (due to the usually but not always higher growth in the omitted activities) are best overcome by periodic changes in the base year. The problems of inconsistency of overall levels of activity estimated as between the ASI, CMIE and the MCA/RBI database for the private sector both of gross capital formation and of gross value added have been covered by Nagaraj. R. (2015). Here we are focused on the growth rate differences which are debilitating to the analysis by macroeconomists since the prospect of macroeconomic understanding an debate could get entirely washed out in the debate on data and estimation methods.
} 
to the units as per the guidelines of the ASI in data collation. Nagaraj, R. (2015) has suggested that the overestimation is on account of the overestimation of the role of the private sector as when the "enterprise accounts" of the RBI are used to infer about the much larger set of companies in the MCA through dubious extrapolation. We do not pursue the issue of reconciling the differences between the two series as a statistician. Instead our attempt is to bring out the difference between what would have been the case had the older series continued - in a certain sense - and the new series, and only laterally to suggest - what could have caused the same.

Our concern in this study is not to get into the nitty-gritty issues of data, extrapolation, deflation, coverage and use of proxies, that statisticians have to go through to estimate national output and income ${ }^{5}$ Goldar (2016), raised the issue of overestimation in growth rate as given by the GVA11-12 with regard to manufacturing, by contrasting the same with the growth rate of the IIP, ASI and credit, and in the previous 04-05 series over the period of overlap.

Herein we seek to project (forecast) what the old measure of GDP04-05 would have resulted in given the pure statistical influences that other variables have on the same. These other variables are necessarily more direct (not involving extrapolation). They are measures like output indices, credit, exports (in rupees), which are therefore more reliable. The influence may be due to causation, association, or may well be embedded in the defining measure of GDP04-05 for a particular sector. An example of the latter is when value added (GDP) is definitionally related to the units of electricity sold. Our task being not to test any behavioral theory, or a causation, but merely to estimate output (growth), any proxy that captures output would be valid. Good fit in the estimation process though is important, so that the estimations (forecasts) can be made with much confidence. The problem of non-stationarity is handled by dealing only with growth rates of all variables which are used in the regressions. Most economic variables when non-stationary - price indices, output indices, GDP, output, etc are a priori expected to exhibit "exponential unfoldment" over time so that log of the ratio of this period value to last period value (quarter on quarter or month on month) when de-seasonalised would be stationary and exhibiting only short period covariance due to business cycles.

Using $X_{i}(t)$ to represent the GDP in the $\mathrm{i}^{\text {th }}$ sector over a quarter indexed by $t$, and $v_{i, j}(t)$ to represent various the $j^{\text {th }}$ independent variable the regressions are all of the form

$\tilde{X}_{i}(t)=\hat{\alpha}_{i}+\sum \hat{\beta}_{i, j} \tilde{v}_{i, j}(t)+e_{i}$ where the $\sim$ sign over the variable represents symmetric growth rates. Since we have only short period autocorrelation and there is no time trend or an integrating process, the $R$ or $\bar{R}$ sq. will not be large, and getting large values would imply a good fit making the estimation (forecast) robust. The values of the coefficients are of little meaning, since it is the overall equation that matters. $v_{i, j}$ 's for a particular $X_{i}$ are chosen based on a prior definitional (measurement) near identity, and proxing behavior that has an a priori justification. More often than not it is the former. Thus if manufacturing GDP is known to be composed (additive sum) of n-sectors, then we would expect very large dependence of the growth rate of mfg. GDP on the growth rates of the various indices that reflect the subsectors that constitute the component sectors. When a proxy like credit growth is also used and then of course the predicted value (estimates) cannot be used to study the relationship between credit and growth. The merit of the method is that when used over a relatively short period to estimate growth i.e. $\tilde{X}_{i}(t)$, then since the growth rates are range bound, and the independent variables are directly measures $-\tilde{v}_{i, j}(t)$ over the forecast period, the forecast (estimation) is essentially "insample", and for the period over which there is data for the set of independent variables.

The analysis has been carried out separately for the following sectors of the National Accounts Statistics (NAS).

(i) Manufacturing

(ii) Electricity, Gas and Water

(iii) Mining and Quarrying

(iv) Construction

${ }^{5}$ CSO (2018, July 15) made a whole host of recommendations to improve the data gathering process, improve timeliness, and enhance reliability. However, it did not go into investigating the reasons for the significant differences between the old and the new series. 
(v) Services
a. Community, Personal and Social Services
b. Finance, insurance, real-estate and business services
c. Trade, hotels, transport, storage and communication

Since the services sectors are disparate, the growth rates for the three subsectors were separately estimated. Since the independent variables for estimating GDP in manufacturing are all physical indices (Indices of Industrial Production - IIPs), the estimates are much more reliable. For some of the services sectors, the independent variables are more proxies than output indicators, so the estimations are less reliable.

\section{GDP GROWTH IN THE MANUFACTURING SECTOR}

The independent variables are the growth (quarter on quarter) in IIPs of various sectors / goods for which the IIP data is available at the 2-digit level. The data on the IIP (2011-12) series is available only from the second quarter of 2011-12. So the IIP (2004-05) has been normalized to chain IIP04-05 and IIP11-12 together to give a long enough time series. The chaining has been done by using the ratio of the average geometric value of IIP11-12 (4 quarters - 12:2, 12:3, 12:4 and 13:1) to the geometric average of the IIP04-05 over the same quarters, over which the data from both series are available. The IIPs for Food and for Beverages in the 11-12 series had to be added together, using their weights, to make the same backwardly compatible with IIP04-05 for Food and Beverages, before chaining. Then the growth rates in these chained series were used as independent variables, to estimate the growth rate of GDP-Manufacturing.

Using the above coefficients the values of the growth rates in GDP04-05 was forecasted (estimated) for the period from 2012:2 onwards and compared with the growth rates in GVA11-12 -Manufacturing at constant 11-12 prices. This is Model 1. The Adj.R-sq for the model was 0.83.

Next a principal component analysis of all the 2-digit chained IIPs (growth rates) was carried out and the top 7 principal components selected as independent variables (Model 2) and with top 11 components as independent variables (Model 3). The forecasts are only marginally different. Next from the set of independent chained indices (growth rates) only those that were significant were selected (Model 4) and that gives the best results though only marginally different from Model 1. Using only one regressor - the growth rate in the chained IIP for overall manufacturing (Model 5) was also carried out. In summary the adj-R-sqs was highest (0.88) for the model with only the significant IIPs and hence the results of the same were used to carry forward to the projections of overall GDP. However, all models gave the same results for the period up to 2017:2 but differed somewhat for the period from 2017:3. The plots for the growth rates in GVA11-12 and in GDP04-05 (estimated) for Model 4 are also presented in Fig. 4. The regression results are in Table 2. 


\begin{tabular}{|c|c|c|c|c|c|c|c|c|c|c|c|c|c|c|c|}
\hline \multicolumn{16}{|c|}{ Table1 : GDP04-05 and GVA11-12 Series Over the Quarters where Both Series are Available } \\
\hline & $\begin{array}{l}\text { GDP04- } \\
05 \text { at } \\
\text { current } \\
\text { prices } \\
\text { (Rs b) }\end{array}$ & $\begin{array}{l}\text { GVA11- } \\
12 \text { at } \\
\text { current } \\
\text { prices } \\
\text { (Rs b) }\end{array}$ & $\begin{array}{l}\text { Ratio of } \\
\text { GVA to } \\
\text { GDP } \\
\text { (both at } \\
\text { current } \\
\text { prices) } \\
\text { (B/A) }\end{array}$ & $\begin{array}{l}\text { Growt } \\
h \text { rate } \\
\text { of } \\
\text { GDP } \\
\text { at } \\
\text { current } \\
\text { prices }\end{array}$ & $\begin{array}{l}\text { Growt } \\
\text { h rate } \\
\text { of } \\
\text { GVA } \\
\text { at } \\
\text { current } \\
\text { prices }\end{array}$ & $\begin{array}{l}\text { GDP04- } \\
05 \text { at } \\
\text { constant } \\
\text { prices } \\
\text { (Rs b) }\end{array}$ & $\begin{array}{l}\text { Adjusted } \\
\text { GDP04-05 } \\
\text { at constant } \\
04-05 \text { prices } \\
\text { brought to } \\
11-12 \\
\text { constant } \\
\text { prices } \\
\text { (Rs b) }\end{array}$ & $\begin{array}{l}\text { GVA11- } \\
12 \text { at } \\
\text { constant } \\
\text { prices } \\
\text { (Rs b) }\end{array}$ & $\begin{array}{l}\text { Ratio of } \\
\text { GVA to } \\
\text { GDP } \\
\text { both at } \\
\text { constant } \\
\text { prices }\end{array}$ & $\begin{array}{l}\text { Growth } \\
\text { Rate in } \\
\text { GDP04-05 } \\
\text { at constant } \\
\text { prices }\end{array}$ & $\begin{array}{l}\text { Growth } \\
\text { rate in } \\
\text { GVA11- } \\
12 \text { at } \\
\text { constant } \\
\text { prices }\end{array}$ & $\begin{array}{l}\text { Inflatio } \\
\mathrm{n} \text { in } \\
\text { Implici } \\
\mathrm{t} \\
\text { Deflato } \\
\mathrm{r} \text { GDP }\end{array}$ & $\begin{array}{l}\text { Inflati } \\
\text { on } \\
\text { Implic } \\
\text { it } \\
\text { Deflat } \\
\text { or } \\
\text { GVA }\end{array}$ & 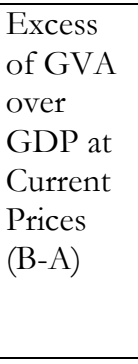 & $\begin{array}{l}\text { Excess } \\
\text { of GVA } \\
\text { over Adj } \\
\text { GDP at } \\
\text { constant } \\
\text { prices } \\
(\mathrm{I}-\mathrm{H})\end{array}$ \\
\hline & A & $\mathrm{B}$ & $\mathrm{C}$ & $\mathrm{E}$ & $\mathrm{F}$ & G & $\mathrm{H}$ & I & $\mathrm{J}$ & K & $\mathrm{N}$ & $\mathrm{O}$ & $\mathrm{P}$ & Q & $\mathrm{R}$ \\
\hline 2011:2 & 20,684 & 19,165 & 0.927 & 0.170 & & 13,219 & 20,684 & 19,691 & 0.952 & 0.080 & 0.091 & & & $-1,519$ & -992 \\
\hline 2011:3 & 20,852 & 19,003 & 0.911 & 0.154 & & 13,212 & 20,673 & 19,132 & 0.925 & 0.065 & 0.090 & & & $-1,849$ & $-1,541$ \\
\hline 2011:4 & 23,560 & 20,912 & 0.888 & 0.141 & & 14,482 & 22,660 & 20,739 & 0.915 & 0.060 & 0.082 & & & $-2,648$ & $-1,921$ \\
\hline 2012:1 & 25,002 & 21,990 & 0.880 & 0.124 & & 15,418 & 24,125 & 21,507 & 0.892 & 0.055 & 0.070 & & & $-3,012$ & $-2,617$ \\
\hline 2012:2 & 23,087 & 21,874 & 0.947 & 0.110 & 0.132 & 13,743 & 21,505 & 20,746 & 0.965 & 0.039 & 0.052 & 0.071 & 0.080 & $-1,213$ & -759 \\
\hline 2012:3 & 23,413 & 22,022 & 0.941 & 0.116 & 0.147 & 13,829 & 21,638 & 20,479 & 0.946 & 0.046 & 0.068 & 0.070 & 0.079 & $-1,391$ & $-1,159$ \\
\hline 2012:4 & 26,579 & 23,569 & 0.887 & 0.121 & 0.120 & 15,253 & 23,866 & 21,775 & 0.912 & 0.052 & 0.049 & 0.069 & 0.071 & $-3,011$ & $-2,091$ \\
\hline 2013:1 & 28,053 & 24,562 & 0.876 & 0.115 & 0.111 & 16,174 & 25,307 & 22,463 & 0.888 & 0.048 & 0.043 & 0.067 & 0.067 & $-3,491$ & $-2,845$ \\
\hline 2013:2 & 25,469 & 24,414 & 0.959 & 0.098 & 0.110 & 14,322 & 22,410 & 22,062 & 0.984 & 0.041 & 0.062 & 0.057 & 0.048 & $-1,056$ & -348 \\
\hline 2013:3 & 26,586 & 25,119 & 0.945 & 0.127 & 0.132 & 14,543 & 22,756 & 21,939 & 0.964 & 0.050 & 0.069 & 0.077 & 0.063 & $-1,468$ & -817 \\
\hline 2013:4 & 30,027 & 27,061 & 0.901 & 0.122 & 0.138 & 15,926 & 24,920 & 23,149 & 0.929 & 0.043 & 0.061 & 0.079 & 0.077 & $-2,965$ & $-1,771$ \\
\hline 2014:1 & 31,468 & 27,038 & 0.859 & 0.115 & 0.096 & 17,166 & 26,860 & 23,486 & 0.874 & 0.060 & 0.045 & 0.055 & 0.051 & $-4,431$ & $-3,374$ \\
\hline 2014:2 & 28,426 & 28,079 & 0.988 & 0.110 & 0.140 & 15,160 & 23,721 & 23,772 & 1.002 & 0.057 & 0.075 & 0.053 & 0.065 & -347 & 50 \\
\hline 2014:3 & 29,276 & 28,706 & 0.981 & 0.096 & 0.134 & 15,421 & 24,130 & 23,794 & 0.986 & 0.059 & 0.081 & 0.038 & 0.052 & -570 & -336 \\
\hline Avg. & & & 0.921 & 0.123 & 0.126 & & & & 0.938 & 0.054 & 0.067 & 0.064 & 0.065 & & \\
\hline
\end{tabular}




\begin{tabular}{|c|c|c|c|c|}
\hline \multicolumn{5}{|c|}{$\begin{array}{l}\text { Table 2: Results of the Regression of Growth in GDP 04-05 - Manufacturing on Growth } \\
\text { Rates in Select Chained Indices of Industrial Production (Model } 4 \text { - Only Significant } \\
\text { IIPs) }\end{array}$} \\
\hline & Coefficient & Std. Error & t-Ratio & P-Value \\
\hline Constant & 0.02667 & 0.0101 & 2.640 & $0.0150^{* *}$ \\
\hline \multicolumn{5}{|l|}{ Independent V ariables - Growth rates in : } \\
\hline Tobacco products & -0.0797 & 0.0504 & -1.582 & 0.1278 \\
\hline Textiles & -0.6000 & 0.1218 & -4.927 & $6.29 \mathrm{e}-05^{* *}$ \\
\hline $\begin{array}{l}\text { Wood and products of wood \& cork } \\
\text { except furniture articles of straw \& } \\
\text { plating }\end{array}$ & -0.1556 & 0.0690 & -2.253 & $0.0346^{* *}$ \\
\hline $\begin{array}{l}\text { Coke refined petroleum products \& } \\
\text { nuclear fuel }\end{array}$ & 0.2583 & 0.0973 & 2.655 & $0.0145^{* *}$ \\
\hline Chemicals and chemical products & 0.4030 & 0.1066 & 3.781 & $0.0010^{* *}$ \\
\hline Other non-metallic mineral products & 0.5687 & 0.1561 & 3.644 & $0.0014 * *$ \\
\hline Basic metals & -0.4550 & 0.1182 & -3.849 & $0.0009 * *$ \\
\hline $\begin{array}{l}\text { Fabricated metal products except } \\
\text { machinery \& equipment }\end{array}$ & 0.2706 & 0.0849 & 3.186 & $0.0043^{* *}$ \\
\hline Electrical machinery \& apparatus n e c & 0.0818 & 0.0150 & 5.435 & $1.85 \mathrm{e}-05^{* * *}$ \\
\hline Motor vehicles trailers $\&$ semi-trailers & 0.2725 & 0.0417 & 6.529 & $1.44 \mathrm{e}-06^{* * *}$ \\
\hline Rubber products & -0.1114 & 0.0862 & -1.292 & 0.2099 \\
\hline Mean dependent var & 0.0648 & \multicolumn{2}{|c|}{ S.D. dependent var } & 0.0582 \\
\hline Sum squared residues & 0.0091 & \multicolumn{2}{|c|}{ S.E. of regression } & 0.0204 \\
\hline $\mathrm{R}$-squared & 0.9185 & \multicolumn{2}{|c|}{ Adjusted R-squared } & 0.8777 \\
\hline $\mathrm{F}(11,22)$ & 22.537 & \multicolumn{2}{|l|}{ P-value (F) } & $1.85 \mathrm{e}-09$ \\
\hline Log-likelihood & 91.564 & \multicolumn{2}{|c|}{ Akaike criterion } & -159.1273 \\
\hline Schwarz criterion & -140.811 & \multicolumn{2}{|c|}{ Hannan-Quinn } & -152.8809 \\
\hline rho & -0.2766 & \multicolumn{2}{|c|}{ Durbin-Watson } & 2.4564 \\
\hline
\end{tabular}

Observe that the growth rates given by the GVA11-12 are well above those given by our estimates for much of the period after 2012:2, but for the period of 2017:2 and 2017:3 the estimates are higher. The reliability of our estimates would decline somewhat over the latter period. Appendix table brings out the estimated growth rates (Model 4) and the growth rates based on GVA on an annual basis being the average of the quarterly growth rates. In every year the estimates were much lower than the GVA based growth except for 2017-18 where we had estimates for only 3 quarters, and the estimates are less reliable. See Fig. 4. See also Table 4.

\section{CERTAIN OTHER SECTORS}

W. P. No. 2019-01-01 
Again the index for electricity of 04-05 was chained to the index of 11-12 and the growth rates of the same were used to estimate the GDP Electricity, Gas etc. growth rates. There was no physical and readily available index for gas and water production, and hence this single variable model was retained with an overall adj-R-sq of 0.54 , which is much lower than desirable. For Mining and Quarrying as well the same procedure of using only the index for mining was used. (Adj. R-sq of 0.25).

For the GDP in construction, we developed two models. In the first instance we used all two digit manufacturing indices, along with the indices for electricity, and mining and quarrying to estimate the GDP04-05 growth in construction. (Adj-R-sq. of 0.84). In the second model we took only the significant variables (Adj R-sq of 0.89 ). The estimates were very close. In this case our models gave estimates of growth rates that was somewhat higher than that given by the GVA11-12 growth rates.

\section{THE SERVICE SECTORS}

Price indices, net sales figures in current rupees, and "inflows" i.e. imports and exports of services of some items were used. Price indices of nearly 20 items CPI2001-IW for which the longest series were available constituted the set of price indicators. The net sales pertained to 16 items, and the "inflows" to 20 items ${ }^{6}$. The growth rates of each of variables were computed to be used. For the CPI variables the principal components of the growth (inflation) in the same were computed from the 20 original CPI items. The major principal components were used in the models for various service subsectors. The dependent variable is the growth in GDP04-05 in the particular subsector of the services sector, at constant prices.

For GDP04-05 constant price - Community and Personal Services, the net sales of the health industry -corporate sector, the educational sector credit, incremental non-food credit (housing sector), and 4 principal components from the CPI's principal components were used. The model was estimated with an Adj-R-sq. of 0.43, and the estimation (forecasts) made for the period after 2012:2.

For GDP04-05 constant price - Financing, insurance, real estate and business services, the variables used were: Net sales- Business services and Consultancy industry; Net sales - Construction and Real Estate industry; Inflows of computer services (in Rupees); Inflows of Pension and Insurance Services; Inflows of computer services (in US \$); and four principal components of the inflation in CPI. The model had an Adj. R-sq of 0.76.

For GDP04-05 constant price - Trade, hotel, transport, storage and communication the variables used were: Net sales - Transport industry; Net sales - Communication services industry; Net sales - Storage and distribution industry; Inflows Transport; Nonfood sector gross bank credit -Roads; Non-food sector gross bank credit Transport; Nonfood sector gross bank credit -Shipping; PC1 and PC4. The model had an Adj.R-sq of 0.95.

Now for the growth rates in GDP04-05 -Service sector as a whole, the base values for each of the subsectors were taken and the unfoldment over time of the same with the estimated (forecasted) growth rates was made, and the three subsectors so generated were added together. And from this estimated GDP04-05 for services as whole was

${ }^{6}$ All data for this study was taken from the "Economic Outlook" data base of the Centre for Monitoring the Indian Economy (CMIE) database and the OLS and Principal Components procedures of GRETL were used. Net sales are interim corporate sector aggregates of the CMIE on an number of services. "Inflows" are items on the balance of payments on a number of nonfactor services, taken from the CMIE. 
arrived at from which the growth rates were computed. Table 3 below summarizes the growth rates as predicted and also gives the growth rates in the GVA11-12 at constant prices. Observe that the overestimation is largely on account of the subservice Trade, transport, storage, hotels, and communication services - which are closer to manufacturing than the others. The "overestimation" is not much, or there is underestimation for the some of the other service sectors. For the years 2015-16 and 2016-17 there is significant "underestimation". Our estimations are much more reliable for the Trade, transport, storage, hotels and communication services, with high adj-R-sq. and more direct proxies for output.

Table 3: Estimated Growth Rates GDP04-05 and Growth Rates of GVA11-12, at Constant Prices (\% per annum)

\begin{tabular}{|c|c|c|c|c|c|c|c|}
\hline & & $\begin{array}{l}2012- \\
13\end{array}$ & $\begin{array}{l}2013- \\
14\end{array}$ & $\begin{array}{l}2014- \\
15\end{array}$ & $\begin{array}{l}2015- \\
16\end{array}$ & $\begin{array}{l}2016- \\
17\end{array}$ & $\begin{array}{l}2017- \\
18\end{array}$ \\
\hline \multirow[t]{2}{*}{ Community, personal and social services } & A & 7.89 & 3.83 & 9.58 & 9.63 & 9.72 & 4.40 \\
\hline & B & 4.21 & 3.89 & 7.99 & 5.91 & 10.09 & 9.61 \\
\hline \multirow[t]{2}{*}{$\begin{array}{l}\text { Financial, insurance, real estate and business } \\
\text { services }\end{array}$} & A & 10.46 & 11.85 & 9.38 & 12.82 & 13.59 & 10.03 \\
\hline & $\mathrm{B}$ & 9.32 & 10.36 & 10.45 & 10.23 & 5.44 & 6.38 \\
\hline \multirow[t]{2}{*}{$\begin{array}{l}\text { Trade, transport, storage, hotels, and } \\
\text { communication services }\end{array}$} & A & 4.98 & 2.87 & 3.99 & 10.14 & 6.01 & 1.45 \\
\hline & $\mathrm{B}$ & 9.36 & 6.28 & 8.93 & 9.69 & 7.02 & 7.72 \\
\hline \multirow[t]{2}{*}{ All services } & A & 7.37 & 6.08 & 7.09 & 11.01 & 9.40 & 5.38 \\
\hline & $\mathrm{B}$ & 8.02 & 7.38 & 9.38 & 9.11 & 7.22 & 7.63 \\
\hline
\end{tabular}

A- Estimate of the the growth rate in GDP04-05 at constant prices; B- Growth rate in GVA11-12 at constant prices

Fig. 5 below gives the picture over quarters for the Trade, transport, storage, hotels and communication subsector.

\section{ALL SECTORS}

For the Agricultural sector that includes Animal Husbandry, Forestry and Fishing, we have presumed that for both GDP and GVA since effectively the same method of using proxies for output would have continued, GDP04-05 was extended to the later period using the growth rates in GVA11-12. As such for this sector the issue of under or over estimation was not addressed. Over the overlap period there is a small difference between the GDP04-05 growth rates and the growth rates in GVA11-12. The GDP04-05 for the period thereafter was extended by use of the GVA growth rates.

With all sectors being covered the growth rates of GDP04-05 (all sectors) could be computed and compared with the growth rates for GVA11-12. These are reported in Table 4. 
Table 4 : Growth Rates of National Income Sectors (Estimated GDP04-05, and GVA11-12) at Constant Prices (\% per annum)

\begin{tabular}{|l|l|r|r|r|r|r|r|}
\hline & & $2012-13$ & $2013-14$ & $2014-15$ & $2015-16$ & $2016-17$ & \multicolumn{1}{l}{$2017-18$} \\
\hline Manufacturing & A & 1.66 & 0.44 & 0.20 & 3.56 & 5.66 & 8.21 \\
\hline & $\mathrm{B}$ & 5.40 & 4.89 & 7.54 & 12.01 & 7.64 & 4.21 \\
\hline Mining and Quarrying & $\mathrm{A}$ & -0.50 & 1.54 & 1.12 & 3.27 & 3.53 & 2.59 \\
\hline & $\mathrm{B}$ & 0.46 & 0.11 & 8.90 & 12.90 & 11.82 & 2.84 \\
\hline $\begin{array}{l}\text { Electricity, Gag and } \\
\text { Water }\end{array}$ & $\mathrm{A}$ & 5.12 & 6.16 & 10.53 & 5.99 & 6.08 & 5.78 \\
\hline & $\mathrm{B}$ & 2.63 & 4.07 & 6.97 & 4.63 & 8.86 & 6.74 \\
\hline Construction & $\mathrm{A}$ & 1.67 & 1.63 & 5.09 & 6.38 & 2.45 & 6.87 \\
\hline & $\mathrm{B}$ & 0.30 & 2.69 & 4.24 & 3.63 & 1.37 & 3.63 \\
\hline Agriculture etc. & $\mathrm{A}$ & 1.48 & 4.65 & 0.64 & 0.96 & 5.92 & 3.13 \\
\hline & $\mathrm{B}$ & 1.55 & 5.29 & 0.34 & 0.96 & 5.92 & 3.13 \\
\hline Services & $\mathrm{A}$ & 7.37 & 6.08 & 7.09 & 11.01 & 9.40 & 5.38 \\
\hline & $\mathrm{B}$ & 8.02 & 7.38 & 9.38 & 9.11 & 7.22 & 7.63 \\
\hline All Sectors & $\mathrm{A}$ & 4.98 & 4.59 & 4.99 & 8.07 & 7.84 & 5.41 \\
\hline & $\mathrm{B}$ & 5.31 & 5.90 & 6.93 & 7.83 & 6.86 & 5.92 \\
\hline
\end{tabular}

A- Estimated growth rate of GDP04-05 at constant prices; B- Growth rate of GVA11-12 at constant prices; The estimates (A) for 2017-18 are the average for the first three quarters

\section{CONCLUSION}

The large divergence in the growth rate estimates derived through physical indicators used to extend GDP04-05, from the growth rates in the GVA11-12 would especially question the methods of imputation used in moving from a limited sample of firms' accounts to all firm accounts in the new series - GVA11-12, as has been questioned by both Nagaraj, R.(2015), and the RBI (2015). The problem is quite severe in the case of manufacturing, where the new estimates seem to be not in tune with growth determinants.

It is a matter than needs to be resolved and the CSO cannot just claim that the difference is not their problem since they are following the most modern and standard SNA approach of building national income through the value added method. Only complete openness in revealing and sharing the methods used for imputation / extrapolation with scholars outside officialdom would help since the matter would require the effort of all interested minds. This is especially so because there are far too many imputations that are made in the new approach.

That accounts do not cover a large part of the economy and even when there are accounts for enterprises, the fact that the delays in the same are about large or larger than for the ASI would question the enterprise based approach. Moreover, the vast difference (little convergence) between GVA early estimates and revised estimates would remove any utility for the GVA in discerning the trends over time of so important and central a sector as manufacturing. 
Going by the growth rates of the older GDP extended, it is highly unlikely that India has maintained as high a growth rate as 7.2 to $7.5 \%$ over the last several years. Barring two years 2015-16 and 2016-17 when growth had possibly picked up only to dashed by demonetization and other quixotic initiatives of the government, the growth was most likely under 6\% and closer to $5-5.5 \%$.

In manufacturing the growth may have been very low except apparently in the last three quarters which may reflect a partial bounce back from the effects of demonetization. The poor performance of manufacturing would mean that many interesting efforts of the government including "Make in India" may have lacked the strategy (consistent across trade and tariffs, industrial and macroeconomic dimensions of policy) to have had an impact. Thus in the period from 2012-13 to 2016-17 manufacturing GDP growth may have averaged as low as $2.3 \%$ per annum to rise in $2017-18$ (three quarters) to $8 \%$ or so.

It seems that during a down turn the new measure does not move quickly enough. Perhaps one reason which suggests would be terms of trade effect. Since the accounting data would be at current price and the current price value added would be deflated by the price index for the output (at a broader category) small firms would suffer large terms of trade losses during a down turn especially (but even otherwise) when they are in vendor relationship with large firms. This would overstate the value addition in both real and nominal terms of the larger corporate sector. Moreover, when the trend in the large (data available sector) is used to impute the growth in the smaller sector, there is an inbuilt bias that keeps the growth rates higher in the GVA11-12, during slowdowns. If true, this would also seriously question the liberal use of value added per "effective labour input method" that is resorted to. Hence it becomes important to condition the output indicators by final goods measures / indicators. It would reiterate the importance of indices of production and of the ASI as many others have argued. To invest in the ASI and to make the same somewhat more comprehensive and quicker to gather and collate would be the way forward.

More generally the search for comprehensiveness, would, beyond a point, be in conflict with the need for reliable (and early available) measures of growth, if much of the greater comprehensiveness is to come largely through imputations that ignore behavioural differences between those entities and activities for whom the data has to be imputed from others for which the data is available.

\section{References:}

Dholakia, Ravindra, R. Nagaraj and Manish Pandya (2018), Manufacturing Output in New GDP Series - Some Methodological Issues”, Economic and Political Weekly, No.35, Vol. LIII, September 1, pp.10-13.

Nagaraj, R. (2015), "Seeds of Doubt on New GDP Numbers - Private Corporate Sector Overestimated?”, Economic and Political Weekly, No.13, Vol. L, March 28, pp.14-17.

CSO(2018, July 15), "Report of the Committee on Real Sector Statistics", Central Statistical Organisation.

Goldar, Biswanath (2016), "Manufacturing Growth in India in Recent years - Is it getting overstated in India's new GDP series?", Indian Growth and Development Review, Vol.9, No.2, pp. 102-113.

RBI (2015), “Monetary Policy Report - April”, Reserve Bank of India

Ministry of Finance (2015), Economic Survey 2014-15, Ministry of Finance, Government of India 
Fig 1:

Growth Rates in GDP and GVA

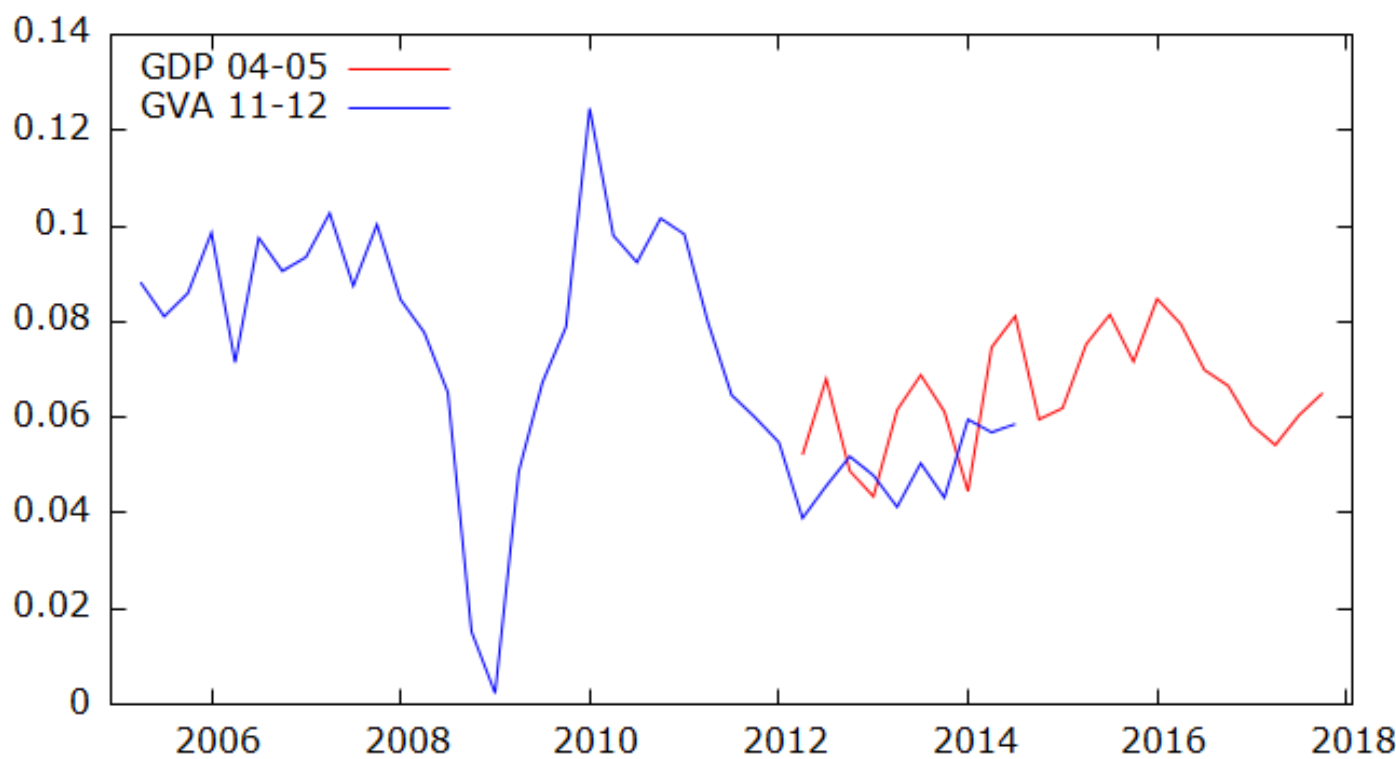

Fig. 2

Growth Rates in Nominal GDP and GVA

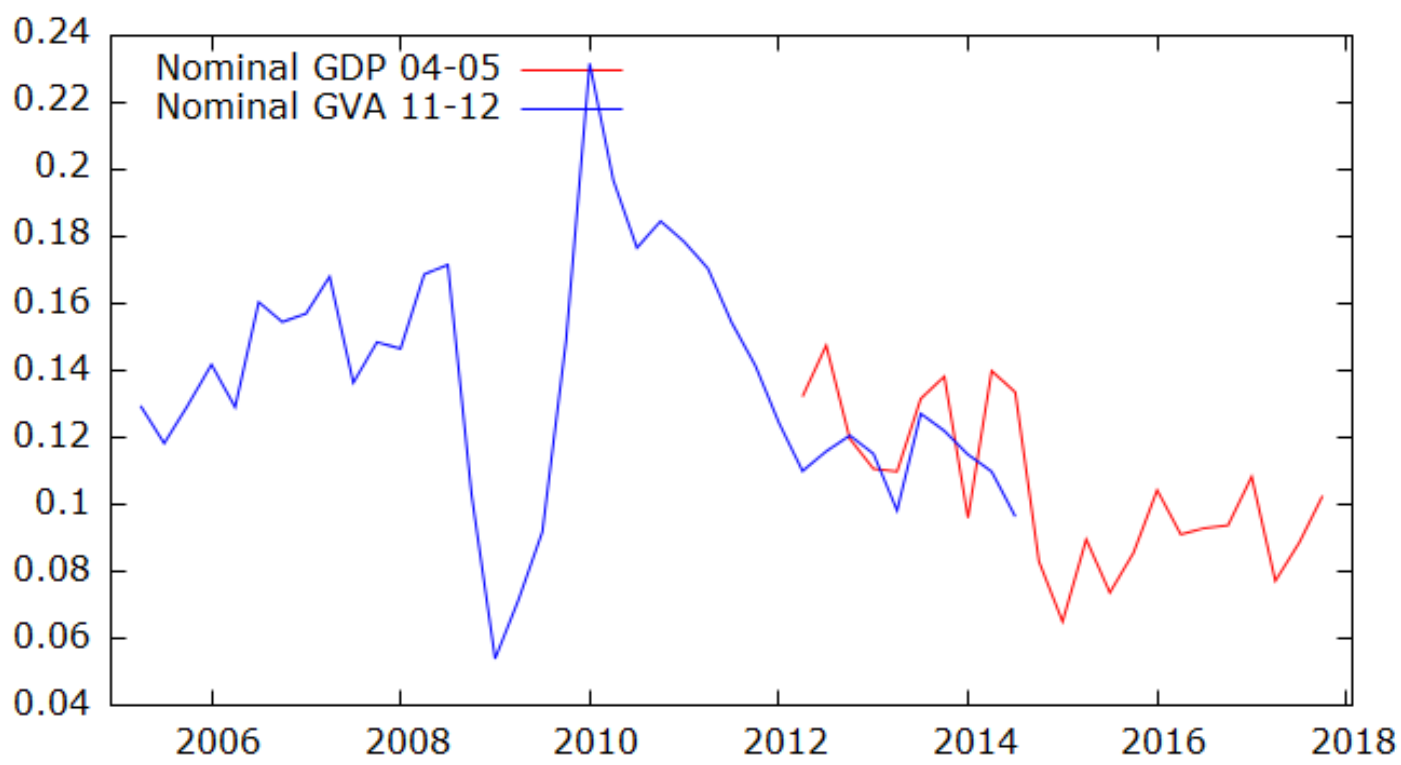

Fig. 3

W. P. No. 2019-01-01 


\section{Inflation in Implicit Deflators GDP and GVA}

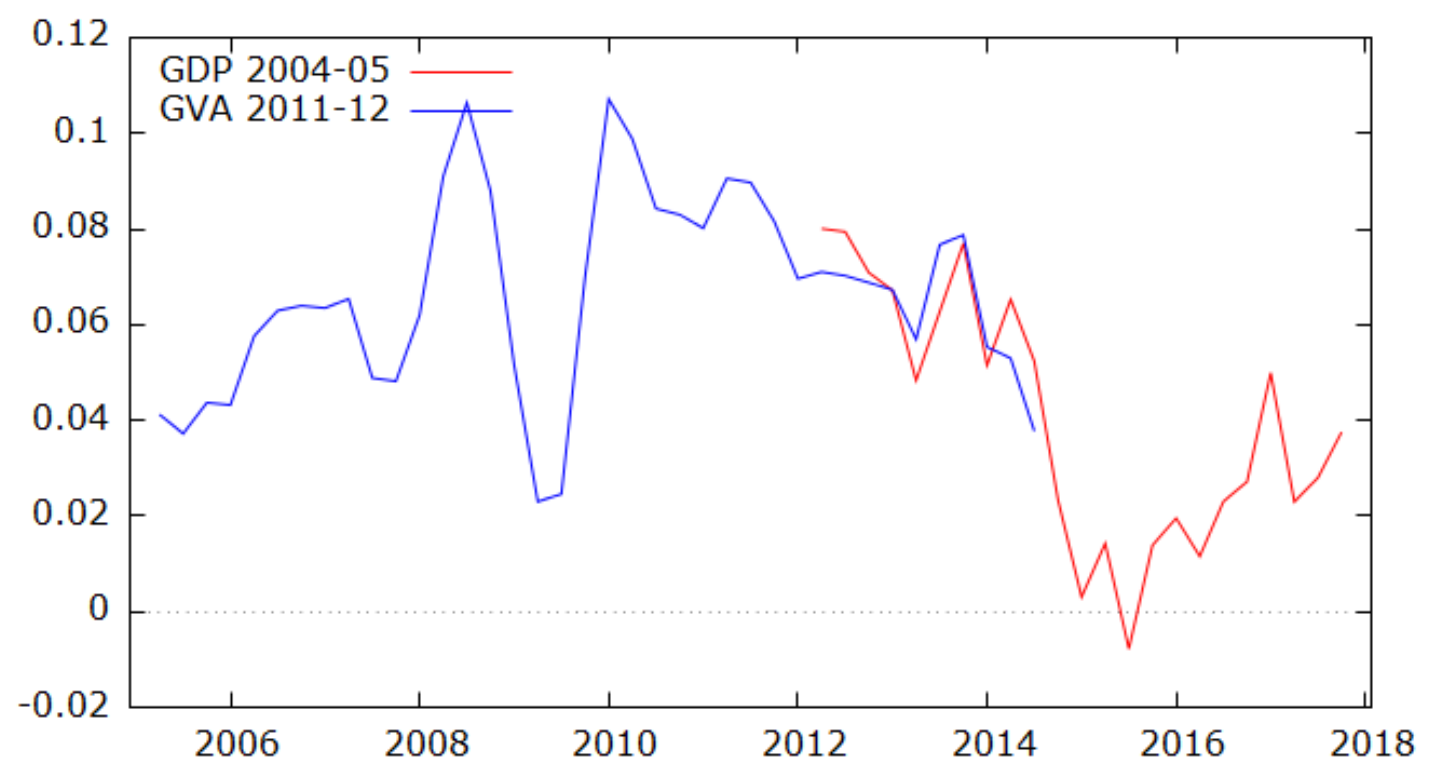

Fig. 4: Growth Rates of Mfg Output (Model 1 and Model 4)

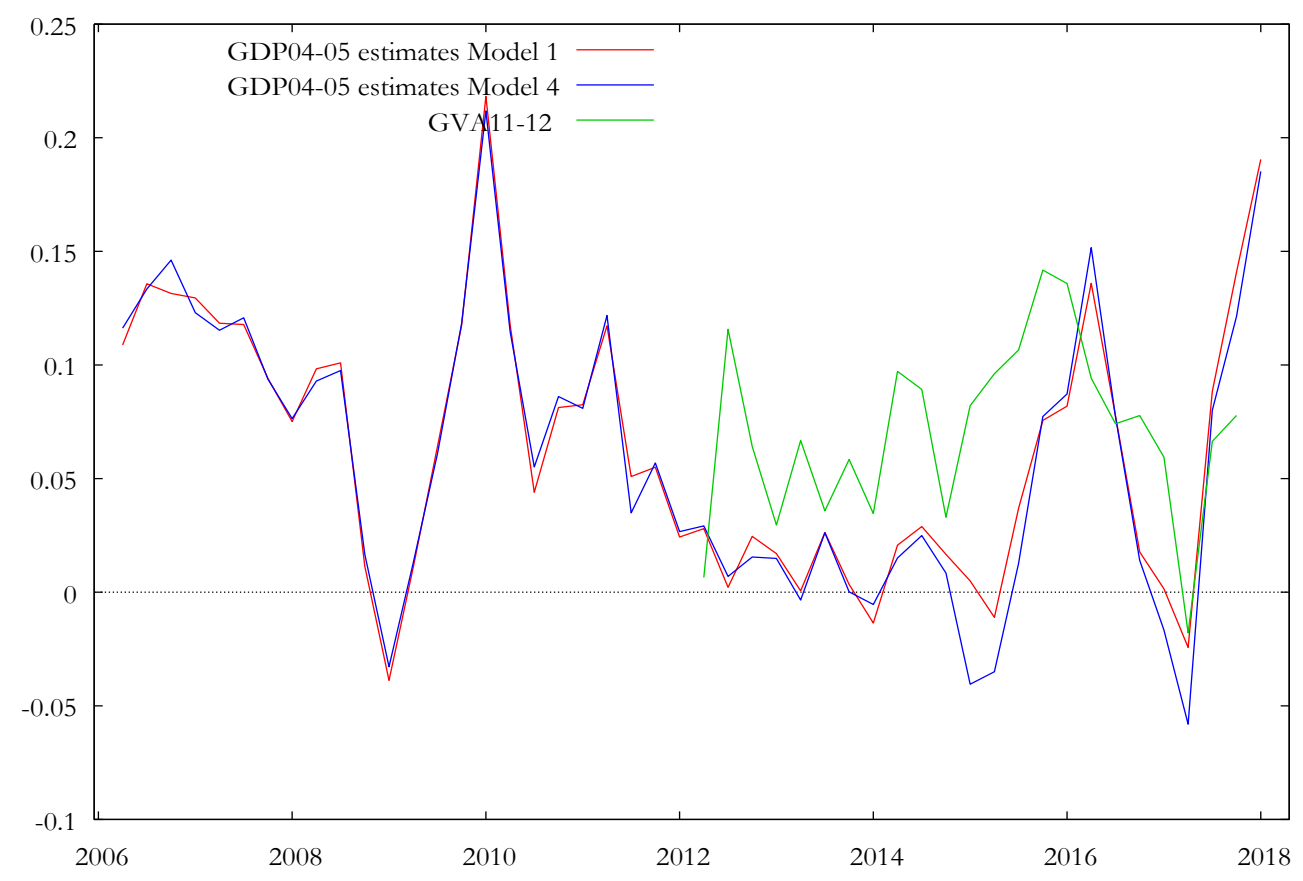

W. P. No. 2019-01-01 
Fig. 5

Growth Rates - Trade, Transport Storage and Communication (At Constant Prices)

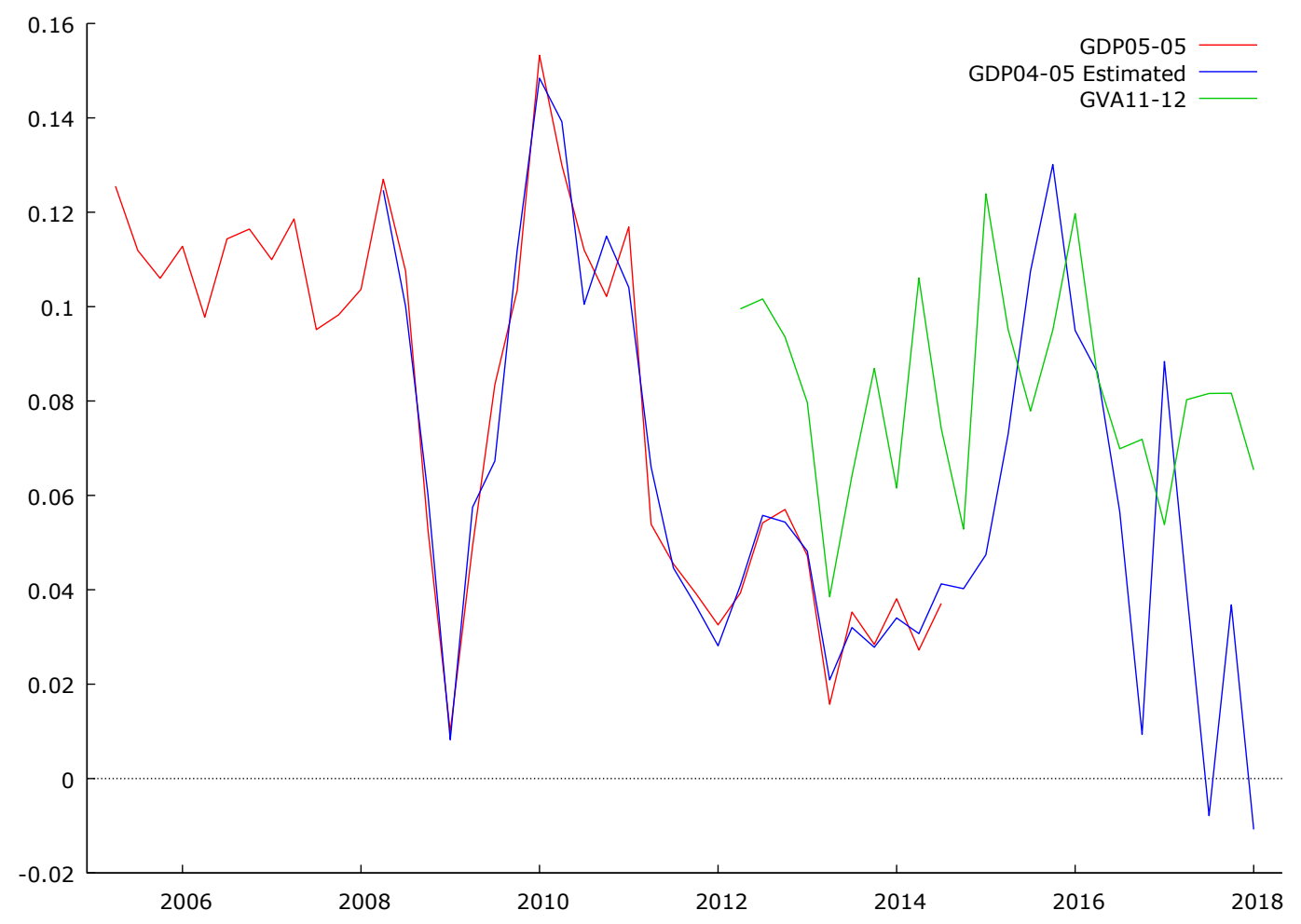

W. P. No. 2019-01-01 